\title{
Distribution and Use Patterns of Small-Scale Rice Mills in Kampar Regency, Riau Province, Indonesia
}

\author{
Ujang Paman, Saipul Bahri, Asrol and Limetry Liana \\ \# Department of Agribusiness Faculty of Agriculture Riau Islamic University, Pekanbaru, Riau, Indonesia \\ E-mail: u_paman@yahoo.com; saipulbahri.uir@gmail.com; asrolmkh67@yahoo.com; limetryliana@yahoo.co.id
}

\begin{abstract}
Milling process is the most completely mechanized in rice farming operations in Kampar Regency, Indonesia. Small-scale rice mills are the most popular used by rice farmers and widely distributed over paddy areas in the region. Accordingly, a survey was conducted to recognize the distribution and use patterns of the small-scale rice mills. A total of 20 small-scale rice mills were observed from selected districts of the regency and the machines' owners and operators were interviewed to collect field data. The results showed that the distribution of the small-scale rice mills was concentrated in a wider area of paddy field with a high level of production due to a high demand of milling rice in the areas. Because of most farmers are subsistence in production and the rice will be milled when being consumed, so the small-scale rice mills could be operated along the year. The number of paddy milled in total for a year was 16.4 tonnes for rice mills with a capacity of $750 \mathrm{~kg} / \mathrm{h}$ and 3.9 tonnes for rice mills with a capacity of $500 \mathrm{~kg} / \mathrm{h}$. However, the number of milled paddy varied across months with the peak demand for milling rice occurred after harvesting and before fasting month.
\end{abstract}

Keywords— Use pattern; Small-scale rice mills; Paddy; Milling process; Kampar regency

\section{INTRODUCTION}

Agricultural mechanization in Indonesia was initiated by introducing rice mill in 1950's and followed by hand tractor in the 1960's [1]. In Riau Province, rice mechanization has achieved a significant development in terms of the rice mill utilization among rice farmers. The level of rice milling mechanization in the Province is relatively higher than other rice operations.. Paman et al. [2] reported that mechanization capacity of rice milling operations in Riau Province generally reached nearly $100 \%$ and it is the highest level among rice farming operations in the province. Consequently, the traditional way of processing rice by hand pounding rice in a mortar with pestle was not practiced by farmers anymore. Currently, paddy processing and milling in the province have mostly been performed mechanically at the rice mills. It is because the traditional method is laborious, inefficient, and limited capacity [3]. Efficiency and productivity can be increased for improving machinery usage for both harvesting and processing [4].

Milling is one of labor-intensive operations in postharvest of rice production system. However, paddy (rough rice) must be milled after harvesting and drying [5]. Milling is the process which helps in removal of hulls and barns from paddy grains to produce polished rice [6]. The basic objective of a rice milling process is to remove the husk and the bran layers, and produce an edible, white rice kernel that is sufficiently milled and free of impurities. Husk and bran are not eatable; therefore, they must be removed from paddy [5]. Basutkar et al. [7] stated that milling primarily removes of the germ and bran layers, which contain most of the lipids present in a rice kernel. While rice husk, which is a byproduct of rice, can be used as a source of thermal energy to produce steam for parboiling of raw rice [8]. In addition, in some countries, rice processing sector provides a significant number of jobs to the rural people primarily for women [9]. In Kampar Regency, rice mill is one of farm machines that is operated by hire service groups [10].

The development number of small-scale rice mills in Riau Province has fluctuated during the last 5 years. In 2009, the number of rice mills in the province was 889 units and increased to be 995 units in 2013 [11]. Rice milling is a capital intensive industry [12]. Most of the rice mills are government assistance from farm mechanization development scheme through local government budget (regency or provincial) as well as national budget. The type of the rice mills is small size below capacity of $500 \mathrm{~kg} / \mathrm{h}$. These types are dominant and commonly used by small farmers in Kampar Regency. It is because the rice mills are suitable for rice production that is mostly subsistence due to small rice farming holdings. This study was carried out to 
recognize the distribution and use patterns of the small-scale rice mills in Kampar Regency, Riau Province, Indonesia.

\section{MATERIALS AND METHODS}

A survey was undertaken in seven districts of the Kampar Region of Riau Province, from July to September 2015. Data were collected from 20 small-scale rice mills using purposive sampling methods. The primary and secondary data were used and collected by personal interview with hiring service group managers, machine operators, and mechanics using a pre-structured questionnaire. The primary data gathered including information on machine type and make; seasonal working areas and days; daily working hours; and custom rates. While, the secondary data consisted of number of rice mills, paddy harvested areas and other related data. The data collected were analyzed using descriptive statistical techniques, such as percentage, mean, and others to present the results of the research.

\section{RESULTS AND DISCUSSION}

\section{A. Rice harvested area, production and productivity}

Kampar Regency is one of rice centers in Riau Province. Rice can be found in 17 districts from 21 districts in the regency. The rice is cultivated on wetland and dry land paddy fields and wetland paddy is dominant. Most of the wetland paddy field is grown twice a year, while dry land paddy filed is a single cropping system. According to Table 1 , the wetland paddy contributed an average of about $64.62 \%$ of total harvested area and $78.17 \%$ of total production. Totally, this regency contributes approximately $8.5 \%$ of total rice production in Riau Province.

Fig. 1 shows that the total rice harvested area experiences a fluctuation from year to year. During a period of five years, the total rice harvested area increased about $2.14 \%$ annually on average with the highest harvested area of 27,098 ha in 2012. Contrary, total rice production decreased an average of $6.87 \%$ annually during the same period. The highest total production was 71,656 tonnes in 2012. In addition, the rice productivity decreased to be $9.32 \%$ and $0.15 \%$ for wet land paddy and dry land paddy, respectively. The lowest productivity of wet land paddy was occurred in 2014 as 2.83 tonnes.ha ${ }^{-1}$, while the lowest productivity was also occurred in 2014 as 1.61 tonnes.ha- ${ }^{-1}$.

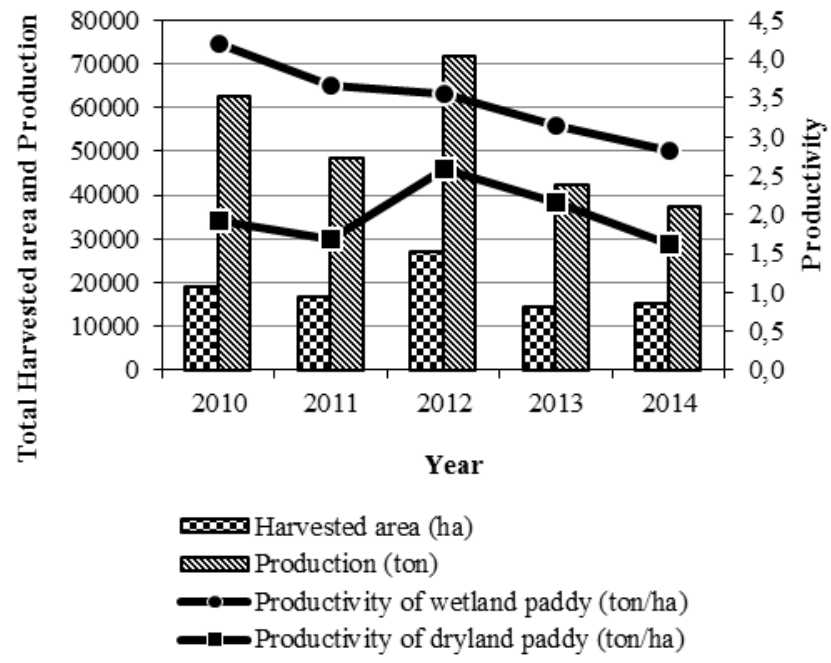

Fig.1. Rice harvested area, production, and productivity during a period of 2009-2014.

Mechanization of rice cultivation in Kampar Regency has gradually evolved, although being limited for several operations, including milling. According to Fig. 2, the availability of rice mills tended to increase during a period of five years. The number of the machines increased from 66 units in 2010 to be 94 units in 2014 with an average growth of $11.51 \%$ annually. Based on the number of rice mills available on the farm, the number of machines per 1000 ha can be known. From Fig. 2 can be seen that the number of machines per 1000 ha tends to slight increase from 4.3 units in 2010 to 6.51 units in 2014 with an average growth of $14.99 \%$ annually.

TABLE I.

Harvested Area, Production And Productivity Of Rice In Kampar Regency During A Period Of 2010-2014.

\begin{tabular}{|c|c|c|c|c|c|c|}
\hline \multirow{2}{*}{ Year } & \multicolumn{3}{|c|}{ Wet land paddy } & \multicolumn{3}{c|}{ Dry land paddy } \\
\cline { 2 - 7 } & Harvested area (ha) & $\begin{array}{c}\text { Production } \\
\text { (ton) }\end{array}$ & $\begin{array}{c}\text { Productivity (ton.ha- } \\
1 \text { ) }\end{array}$ & $\begin{array}{c}\text { Harvested area (ha) } \\
\text { Production } \\
\text { (ton) }\end{array}$ & $\begin{array}{c}\text { Productivity (ton.ha- } \\
\text { ) }\end{array}$ \\
\hline 2010 & 11,436 & $48,020.34$ & 4.20 & 7,592 & $14,515.17$ & 1.91 \\
\hline 2011 & 10,302 & $37,557.44$ & 3.65 & 6,464 & $10,923.63$ & 1.69 \\
\hline 2012 & 14,669 & $52,154.51$ & 3.56 & 12,429 & $19,501.26$ & 2.58 \\
\hline 2013 & 11,355 & $35,747.61$ & 3.15 & 3,077 & $6,654.96$ & \\
\hline 2014 & 10,475 & $29,665.90$ & 2.83 & 4,761 & 2.16 \\
\hline
\end{tabular}

Source: Food Crops and Horticulture Services [13, 14, 15, 16, 17] 


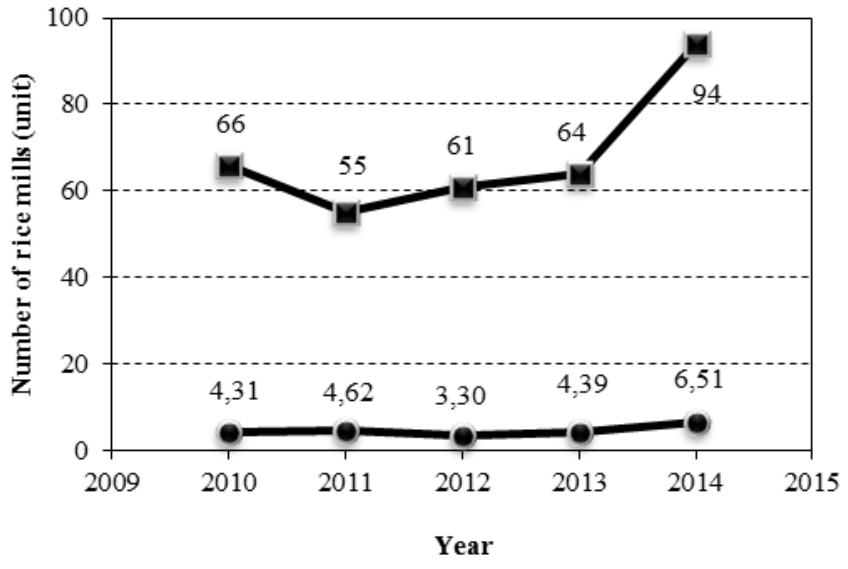

- Total number of RMUs

- Number of RMUs/ 1000 ha

Fig. 2. Number of rice mills in Kampar Regency during 2010-2014.

\section{B. Distribution of rice mills}

The rice mills are commonly spread widely over districts that cultivate and produce rice primary wetland paddy. There are 16 from 21 districts where rice mills are operated in Kampar Regency. The largest number of rice mills is found in Kampar and Tambang to be 15 units each, followed in Kampar Timur and Kampar Utara as 11 and 8 units, respectively. There is a tendency that the number of rice mills becomes larger when the paddy area and production is larger. It means that distribution of the RMUs depends upon the distribution of paddy area.

Based on the number of rice mills operating in the Kampar Regency, the number of hectares per machine can be calculated for each district. This calculation can, then, also describe covering area for each machine in each district. Fig.3 illustrates that the covering area varied across districts and the largest covering area was in Kampar Kiri Hulu to reach 1,250 ha per rice mill, while the smallest of was 150 ha per rice mill found in XIII Koto Kampar.

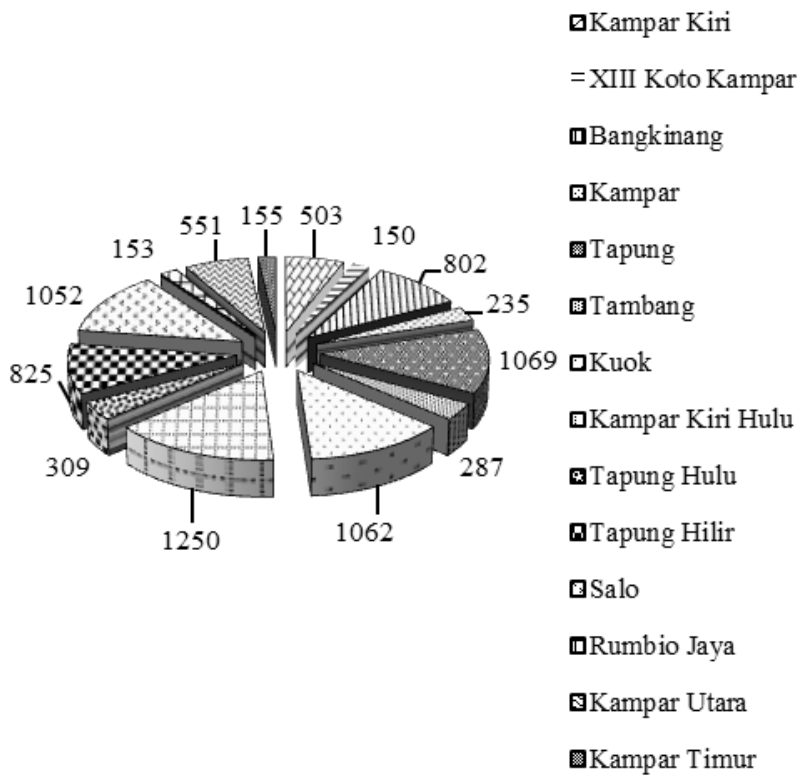

Fig. 3. Covering area for Each Rice Mill and district in Kampar Regency.

\section{Use patterns of mice mills}

The number of power availability and capacity of the rice mills was found to be varied across machines. Two small types of rice mills observed were grouped into two capacities, namely $500 \mathrm{~kg} / \mathrm{h}$ and $750 \mathrm{~kg} / \mathrm{h}$. The rice mills were operated every month along the year. Because most rice farming is subsistence in production, most farmers habitually store the paddy and will just mill it when the rice is needed for consumption. According to Fig. 4, rice mills milled as 16.4 tonnes with an average 1.4 tonnes per months for a capacity of $750 \mathrm{~kg} / \mathrm{h}$, while the rice mills capacity of $500 \mathrm{~kg} / \mathrm{h}$ milled as 3.9 tonnes with an average 0.3 tonnes per month.

TABLE II.

DISTRIBUTION OF RICE MILLS DI KAMPAR REGENCY IN 2014

\begin{tabular}{|c|c|c|c|c|c|}
\hline Districts & $\begin{array}{c}\text { Number of } \\
\text { RMUs }\end{array}$ & Percent & Districts & $\begin{array}{c}\text { Number of } \\
\text { RMUs }\end{array}$ & Percent \\
\hline Kampar Kiri & 5 & 5.32 & Tapung Hilir & 2 & 2.13 \\
\hline XIII Koto Kampar & 4 & 4.26 & Bangkinang Kota & 0 & 0 \\
\hline Bangkinang & 6 & 6.38 & Salo & 4 & 4.26 \\
\hline Siak Hulu & 0 & 0 & Rumbio Jaya & 6 & 6.38 \\
\hline Kampar & 15 & 15.96 & Kampar Utara & 8 & 8.51 \\
\hline Tapung & 1 & 1.06 & Kampar Timur & 11 & 11.70 \\
\hline Tambang & 15 & 15.96 & Kpr. Kiri Tengah & 0 & 0 \\
\hline Kuok & 4 & 4.26 & Gunung Sahilan & 0 & 0 \\
\hline Kampar Kiri Hulu & 1 & 1.06 & Perhentian Raja & 0 & 0 \\
\hline Kampar Kiri Hilir & 1 & 1.06 & Koto Kampar Hulu & 5 & 5.32 \\
\hline Tapung Hulu & 6 & 6.38 & Total & 94 & 100.00 \\
\hline
\end{tabular}

Source: Food Crops and Horticulture Services [17] 
The number of paddy milled varied across months and depended on demand. Interview with owners revealed that the demand for milling services usually increased primarily after harvesting. As shown in Fig. 4, the largest number of milled paddy with a machine capacity of $500 \mathrm{~kg} / \mathrm{h}$ was found in March for about 1.9 tonnes, followed by 1.8 tonnes in July and 1.6 tonnes in April. While the largest milled paddy with machine capacity of $750 \mathrm{~kg} / \mathrm{ha}$ was about 0.9 tonnes for March and the second largest was 0.8 tonnes for July. The paddy was milled mostly after harvesting on March and before fasting month on July.

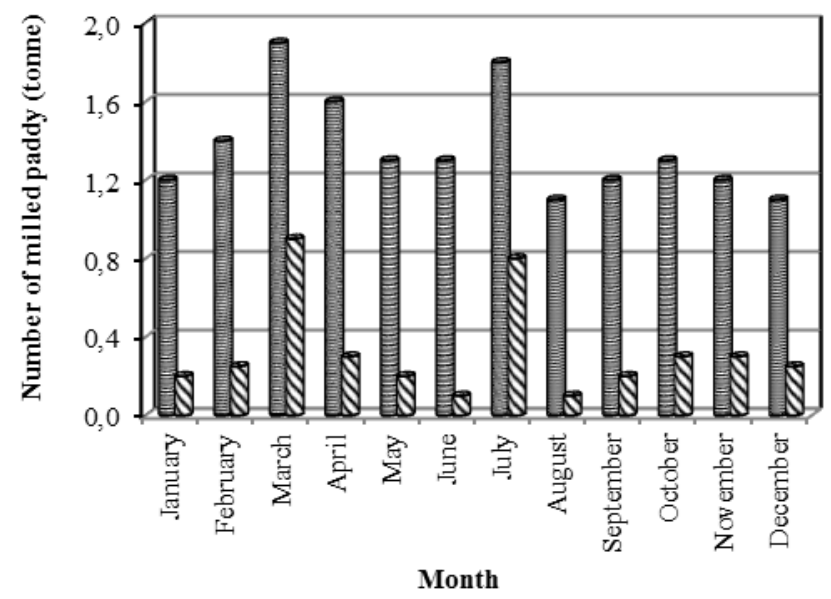

目Rice mills with a capacity of $500 \mathrm{~kg} / \mathrm{h}$

$\mathbf{\Delta}$ Rice mills with a capacity of $750 \mathrm{~kg} / \mathrm{h}$

Fig. 4. Use patterns of rice mills during 2014

\section{CONCLUSIONS}

The distribution of the small-scale rice mills was concentrated in a wider area of paddy field with a high level of production due to a high demand of milling rice in the areas. The largest number of rice mills was found in in Kampar and Tambang to be 15 units each. The rice mills were used along the year with a total of paddy milled was 16.4 tonnes for rice mills with a capacity of $750 \mathrm{~kg} / \mathrm{h}$ and 3.9 tonnes for rice mills with a capacity of $500 \mathrm{~kg} / \mathrm{h}$. Because of most farmers are subsistence and milling only when the rice will be consumed. Consequently, the number of paddy milled varied across months and the largest number was 1.9 tonnes for rice mills with a capacity of $750 \mathrm{~kg} / \mathrm{h}$ and 0.9 tonnes for rice mills with a capacity of $500 \mathrm{~kg} / \mathrm{h}$. The peak demand for milling rice occurred after harvesting and before fasting month.

\section{REFERENCES}

[1] Haeruman, K. M. "Development of agricultural mechanization utilization in West Java (Indonesia)". In Proceedings of Agricultural Mechanization Use Perspective in Increasing Competitive Commodities. E. Syafa'at, N. Hendiarto and R.N. Suhaeti, (Eds.), Bogor, pp. 86-90. 1998.

[2] Paman, U., S. Inaba, S. Uchida. "Determining mechanization capacity and time requirement for farm operations: A case of smallscale rice mechanization in Riau Province, Indonesia". Applied Engineering in Agriculture, Vol. 28, No. 3, pp. 333-338, 2012.

[3] Aworh O. C. "The role of traditional food processing technologies in national development: the West African Experience". In Using Food Science and Technology to Improve Nutrition and Promote National Development, Robertson G. L \& Lupien J. R. (Eds), International Union of Food Science \& Technology, Nigeria, 2008.

[4] Rössel, D., Hipolito Ortiz-Laurel and H.M. Durán García. "Mechanization for harvesting and processing dryland plants". Food, Agriculture \& Environment, Vol. 2, No. 1, pp. 317-321, 2004.

[5] Afzalinia, S., M. Shaker, and E. Zare. "Comparison of different rice milling methods". ASABE, Paper No: MBSK 02- 214, 2002.

[6] Shwetha, M. K. "Business efficiency in rice mills - A comparative analysis of conventional and modern rice mills in Davangere District". Thesis at the Department of Agribusiness Management College of Agriculture, Dharwad University of Agricultural Sciences, Dharwad, 2009.

[7] Basutkar, N. N., T. J. Siebenmorgen, A. Mauromoustakos. "Milling properties of commingled rice-cultivar lots. Transactions of the ASABE, Vol. 57, No. 6, pp. 1717-1728, 2014.

[8] Ahiduzzaman, M and A. K. M. S. Islam. "Energy utilization and environmental aspects of rice processing industries in Bangladesh". Energies, Vol. 2, pp.134-149, 2009.

[9] Zaman, Z. U., T. Mishima, S. Hisano, and M. Gergely. "The role of rice processing industries in Bangladesh: A case study of the Sherpur District". The Review of Agricultural Economics, Vol. 57, pp.121133, 2001.

[10] Paman, U., S. Inaba, S. Uchida. "Farm machinery hire services for small farms in Kampar Regency, Riau Province, Indonesia”. Applied Engineering in Agriculture, Vol. 30, No. 5,pp. 699-705, 2014.

[11] Food Crops and Animal Husbandry Services of Riau Province. "Serial data of food crops and horticultures in 2013, Pekanbaru, 2014.

[12] Shwetha, M. K., S. B. Mahajanashetti and N. M. Kerur. "Economics of paddy processing: A comparative analysis of conventional and modern rice mills". Karnataka Journal of Agricultural Sciences, Vol. 24, No. 3, pp. $331-335,2011$.

[13] Food Crops and Horticulture Services. of Kampar Regency. 2011. Statistical Agriculture 2010. Bangkinang.

[14] Food Crops and Horticulture Services of Kampar Regency. 2012. Statistical Agriculture 2011. Bangkinang.

[15] Food Crops and Horticulture Services of Kampar Regency. 2013. Statistical Agriculture 2012. Bangkinang.

[16] Food Crops and Horticulture Services of Kampar Regency. 2014. Statistical Agriculture 2013. Bangkinang.

[17] Food Crops and Horticulture Services of Kampar Regency. 2015. Statistical Agriculture 2014. Bangkinang. 